\title{
Improving Students Creativity in Producing Instructional Aids for Physics Lesson from Waste and Garbage
}

\author{
Nindha Ayu Berlianti *, Nur Hayati, Oktaffi Arinna Manasikana \\ Science Education Study Program Universitas Hasyim Asy’ari Jombang, Indonesia \\ *Corresponding Author. E-mail: nindhaayuberlianti@yahoo.com
}

\begin{abstract}
The rising of an environmental issue and the lack of the handling of garbage organizing give support to us to do the research by involving garbages as the main material in making simple visual aids of physics. Based on that condition, we try to make new innovations in stimulating the creativity developing of natural science education department students of UNHASY having done the lecturing of basic physics collaborated with environmental science. The purpose of the research is to be able to give insight through education program of $5 R$ (Reduce, Reuse, Recycle, Replace, Respect) to students of natural science department of University of Hasyim Asy'ari and apply that knowledge in changing garbage to be simple visual aids of physics. The method used in this research is qualitative descriptive, whose data can be divided into 3 kinds: observation results (detail description of what has happened in the field), interview results ( direct citation from people's statements in interview session) dan written material. The results of the data are, then analyzed by using observation sheets of creative thinking ability. The main research subjects are 29 students. Meanwhile, the research result is in the form of the average score of students' creativity ability reaching $72.5 \%$ with high category.
\end{abstract}

Keywords: creativity; garbages; simple visual aids

\section{Introduction}

Physics learning aims to make students able to comprehend and acquire real concepts that can be applied in everyday life (Suriawati \& Mundilarto, 2019). Teachers must also use teaching methods and learning media to create conditions for learning activities that give students the freedom to think, assume, and acquire concepts (Nggadas \& Ariswan, 2019).

The existence of waste as a trigger for environmental issues has yet to have economic value. Waste from the results of human and natural activities still needs to be followed up through the process of collecting, transporting, destroying or managing waste in such a way which do not harm human being and its environment.

The lack of a sorting process in controlling waste in the university environment encourages and motivates researchers to conduct a study involving waste as a primary source in the preparation of simple instructional aids for Physics lessons. In previous studies, waste treatment was carried out using the PjBL approach. The results of the research show that the learning process outside the classroom-based project that has been developed was able to foster student creativity in developing projects to reduce waste in the school environment (Astuti, 2015). The use of science learning models with simple instructional aids for practicum activities has a significant influence on the understanding and creativity of Madrasah Tsanawiyah

How to Cite:

Berlianti, N., Manasikana, O., \& Hayati, N. (2019). Improving Students Creativity in Producing Instructional Aids for Physics Lesson from Waste and Garbage. Momentum: Physics Education Journal, 3(2), 86-94.

https://doi.org/10.21067/mpej.v3i2.3395 
students (Budiman, Inggriani, Prasetyo, Fauziah, \& Septiana, 2016). Besides the design of teaching aids can also have an impact on students. Physics learning can be more applicable for students by designing an instructional aid (Amin \& Sustini, 2015). Based on some of the descriptions above, we try to make new innovations by utilizing waste as an instructional aid that is able to stimulate creativity and hone the skills of students of Science Education study programs who have received basic Physics courses and collaborated with environmental science courses.

Developing creativity is done by making products in the form of instructional visual aids for Physics lessons that can be used at the junior high school level by utilizing waste such as used bottles, ice cream sticks, leftover pieces of wood and so on. This instructional visual aid is specifically designed to channel concepts from researchers to students as recipients of concepts and can stimulate thinking, views, raising awareness, and interest in teaching and learning activities which subsequently stimulates learning outcomes. Instructional visual aids must be unique, easy to understand, meaningful, valuable, economical, accessible, and practical in accordance with the criteria of creative products on each indicator of product evaluation (Afriyanto, 2015). Therefore, the assessment of the process and the product of waste management were assessed and evaluated using an observation sheet, according to the students' abilities in each component of the product assessment.

Producing instructional visual aids from waste is one of the suitable strategies in utilizing waste into a valuable object. Therefore, it can reduce environmental pollution and the garbage buildup around the environment of Hasyim Asy'ari University (UNHASY). After the implementation of this research, it is recommended that students of science education study programs can develop creativity and skills in utilizing waste into simple physical teaching aids.

The problems which require to be answered in this research are: how the implementation of $5 R$ education programs among Science Education students in UNHASY and how the creativity of students in the process of making simple instructional visual aids for Physics lessons at UNHASY. This study aims to provide knowledge about the $5 R$ education program (Reduce, Reuse, Recycle, Replace, Respect) to the students of Science Education Hasyim Asy'ari University and to apply the knowledge in utilizing waste into simple instructional visual aids for Physics lesson.

\section{Method}

This study employed a qualitative description method to interpret the phenomena of behavior and utterances performed by the research subjects. The qualitative data taken in this study were detailed descriptions, case documentation, and direct quotes. This study involved 29 students in the 6th semester of the Sciences Education study program.

The basis for choosing this type of research was not to test a hypothesis, but rather to acquire a depiction of the implementation of the $5 R$ waste education program that is applied to foster creativity in making simple instructional visual aid that comes from waste. The basis for consideration in this observation emphasized more on the involvement of researchers because it has the opportunity to transfer knowledge and skills through the courses being taught.

The method of activities carried out as follows: interactive lectures and discussions about the $5 R$ waste education program, then the practice of making physical teaching aids using waste. Data analysis was obtained based on the assessment of students' creativity in turning waste and garbage into simple physics teaching aids, which occurred in two stages, namely the planning stage and the product results stage. The research diagram is presented in Figure 1.

According to (Prasetiyo \& Mubarokah, 2014) to measure the level of creativity of students, they must use a predetermined assessment reference. In this study, the assessment was carried out using a rubric observation sheet. Creativity is expressed as the ability to describe five aspects: (1) understanding information problems (fluency), (2) solving problems with various types of methods (detailing), (3) being 
able to provide an explanation of the various methods of solving them and working effectively with various groups ( flexibility), (4) look carefully at the answers with various methods of resolution, then compose new methods that are different (originality) and (5) ability to evaluate (evaluation) (Marwiyah, Kamid, \& Risnita, 2015). The scoring obtained by students in each stage is added up and converted into a percentage of the value of creativity. The calculation results are then grouped based on the classification of student abilities in Table 1

Tahap Penentuan Ide serta pengamatan awal

Strategi pemanfaatan sampah non degragable yang berpotensi menjadi alat peraga edukasi

$\downarrow$

Identifikasi Masalah

Maraknya isu lingkungan dan kurangnya penanganan dalam mengorganisir sampah

\section{Menetapkan Tujuan}

Memberikan wawasan pengetahuan tentang pengelolaan sampah 5R dan keterampilan dalam mengubah sampah menjadi media pembelajaran (alat peraga)

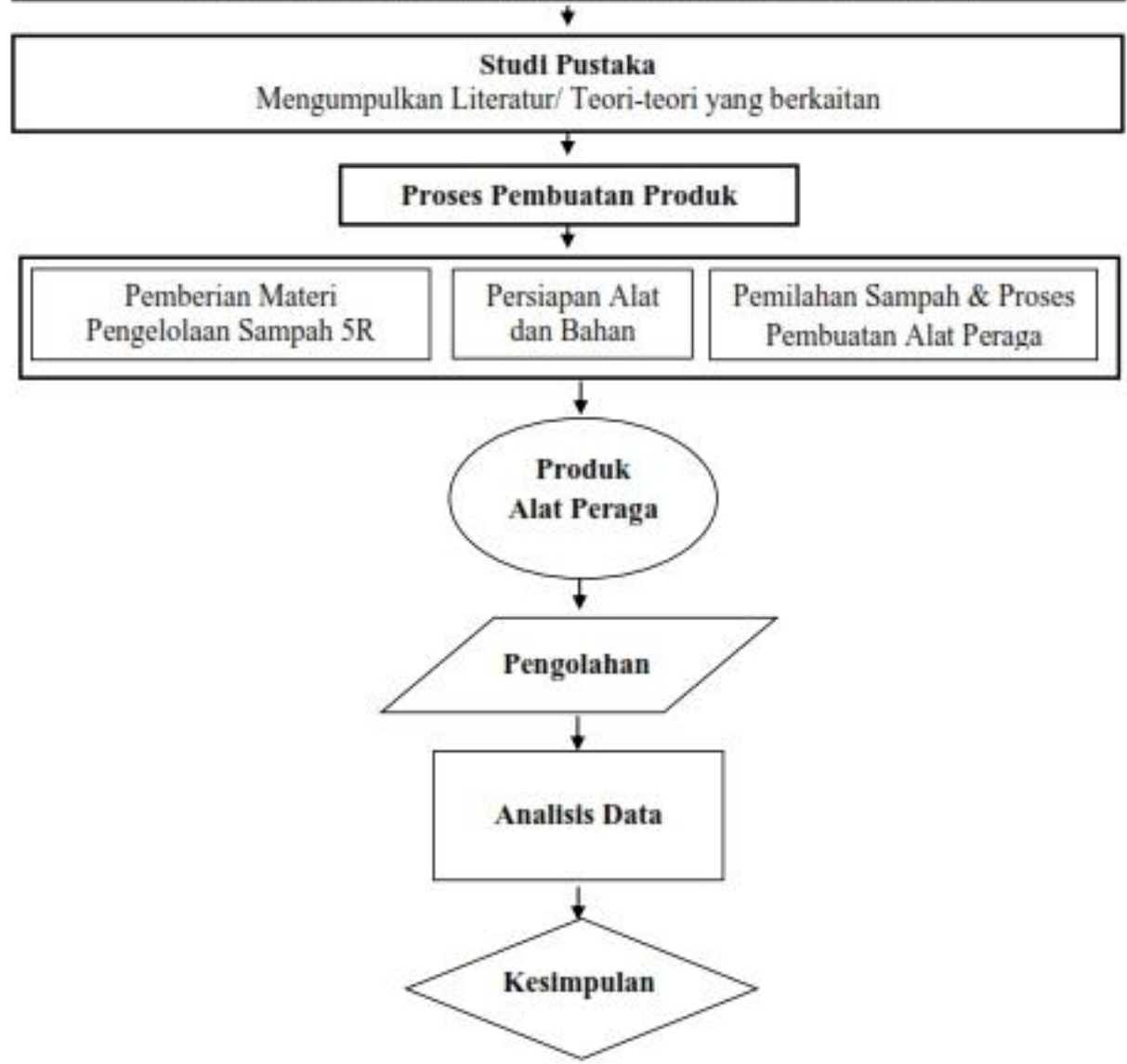

Figure 1. Research Diagram

Table 1. Creative Thinking Classification

\begin{tabular}{cc}
\hline Percentage & Classification \\
\hline $81 \%-100 \%$ & Very High \\
$61 \%-80 \%$ & High \\
$41 \%-60 \%$ & Moderate \\
$21 \%-40 \%$ & Low \\
$0 \%-20 \%$ & Very Low \\
\hline
\end{tabular}

Source: (Sultoni \& Agoestanto, 2013) 
The achievement of performance indicators in this study is to increase student creativity in processing waste. The minimum standard of achievement for the assessment of creativity in this study is $70 \%$ of students received final grades in the high category (Ikromi, 2018)

\section{Results and Discussion}

\subsection{Result}

\subsubsection{The implementation of the $5 R$ education program among students of Science Education UNHASY}

The activities of the $5 R$ education program in this research are carried out through environmental science courses that are applied to students who have taken basic physics. Researchers provide material related to waste management using the $5 R$ method (Reduce, Reuse, Recycle, Replace, Respect) to students. Some of the material presented explains the definition, types of waste along with real examples in daily life and how to distribute the waste according to the $5 R$ method. Then students are divided into 4 heterogeneous groups and given the theme of the problem of how to make physics teaching aids made from rubbish that can be obtained from the environment around the campus. Students are given the freedom to design their own physics teaching aids according to their individual ideas of creativity. The manufacturing process up to the results runs for 4 weeks after giving the material. During the activity process, students are still given guidance and direction so that the teaching aids that are made remain guided by predetermined criteria. These criteria are based on whether or not the teaching aids are used in learning physics in class. Based on the eligibility category, teaching aids must meet several factors: according to the concepts and curriculum of Physics learning, the shape and appearance of the teaching aids must be interesting and in accordance with the needs of students, have a relatively easy level of readability, and can be used or operated easily (Kurniawati \& Atmojo, 2017). Basically, a good instructional aid is an instructional aid that is able to help students strengthen their understanding of learning, be able to attract students' attention, be able to create student imagination with regard to learning material.

\subsubsection{The creativity of Science Education students of UNHASY in making simple instructional aid for Physics lesson after $5 R$ education program implementation}

To support the implementation of a pleasant learning process, adequate teaching aids need to be provided (Hartati, 2010). Instructional aid conceives the understanding that everything that remains abstract is then concreted using a tool or instrument, therefore, it can be comprehended by simple logical process and can be seen and perceived. The existence of instructional visual aids (media) in Physics lessons is very important to support the acquisition of concepts in the learning process (Sutarman, 2014). The instructional aids in this study were used as a media to demonstrate the lesson contents. Instructional aids can be created in accordance with the concepts taught with affordable costs from simple materials that are easily obtained even from used materials (Amalia, 2018). Therefore, waste or garbage could have an added value if it is properly utilized. The implementation of project-based learning can develop students' skills in producing instructional aids for Science lessons by utilizing waste and garbage (Widiyatmoko \& Pamelasari, 2012).

The following discussion is the description of intructional aids products:

\subsubsection{Hydraulic Arm}

It was made of pieces of wood, injection pipette, and popsicle sticks. The hydraulic arm utilizes fluid (liquid) to carry out a movement. The basic principle is when a liquid in a closed space is under pressure, then that pressure will propagate and proceed in all directions equally (evenly, not increasing or decreasing its strength). The statement is better known by the application of Pascal law in hydraulic systems. Simple hydraulic arm instructional aids can be seen in Figure 2 .

\subsubsection{See Saw}


It was made of a popsicle stick, magnetic bar, and piece of wood. Seesaw employs the principle of equilibrium and first class levers with the fulcrum position that lies between the load and the power. Equilibrium at the seesaw is a condition where the load is balanced by power and the fulcrum is the main key in forming equilibrium. If the burden is heavier than the power, the seesaw will tilt towards the load. Static equilibrium in this visual aid occurs if the force acting on the object is equal to $(0)$ and the amount of torque against any point on the object is equal to zero. Stiff body balance requirements If the forces acting on the xy plane. Simple seesaw instructional aid can be seen in Figure 3 .

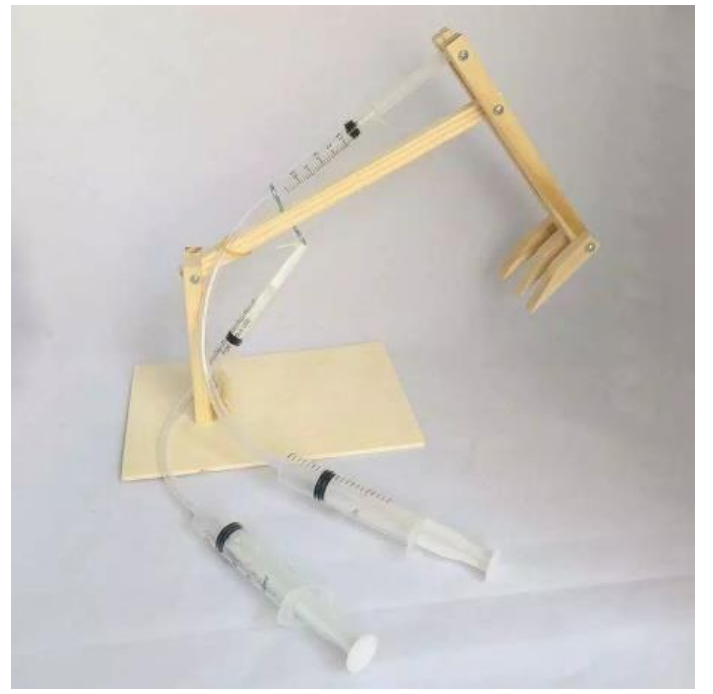

Figure 2. Simple Hydraulic Arm Instructional Aid

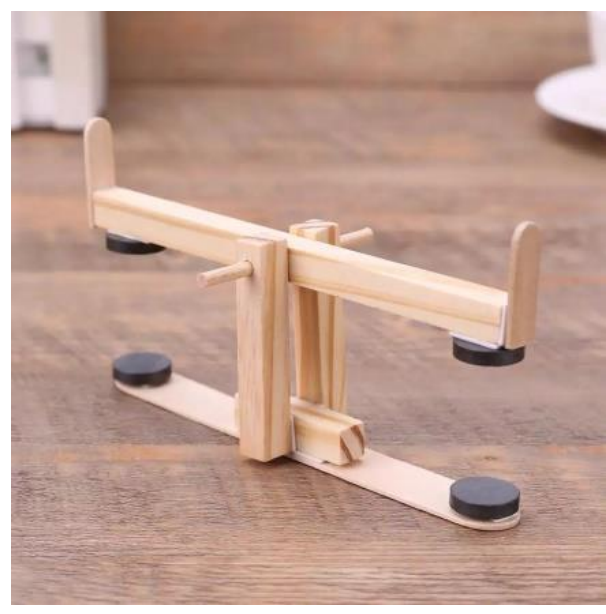

Figure 3. Seesaw Instructional Aid

\subsubsection{Simple Pendulum}

It was made of pieces of wood, strings, and marbles. Simple pendulum applies the concept of simple harmonious motion. Simple harmonious motion is often referred to as oscillation or vibration. The concept of a simple pendulum is the alternating motion of objects through the equilibrium point at fixed time intervals, with the number of vibrations produced in each second always constant. Simple pendulum instructional aid can be seen in Figure 4. 


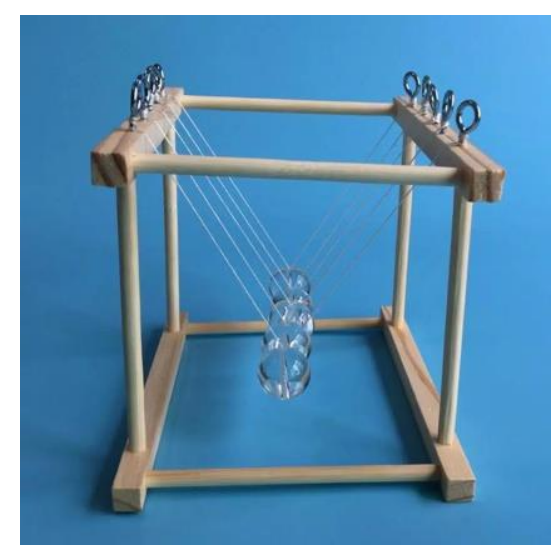

Figure 4. Simple Pendulum

\subsubsection{Simple Baloon Rocket}

It was made of foam, fishing line, straw, and baloon. This simple baloon rocket works if installed balloons and straws will take off on the fishing line until the air in the balloon is completely depleted when the balloon is released, the air will be compressed and go into space so that the balloon will advance like a rocket. The working principle of the rocket is in accordance with Newton III Law theory "For each force of action, will produce the same reaction force but the opposite direction". It is commonly referred to as "Action = reaction" style. Simple rocket instructional aid can be seen in Figure 5.

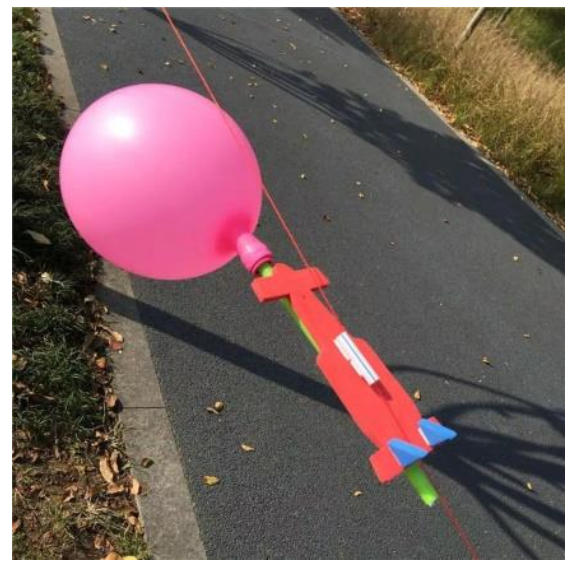

Figure 5. Simple Rocket Instructional Aid

Data about student creativity was obtained from a direct assessment using observation sheets conducted by the research team. The data were then added up and converted into a percentage of students' creative scores during the instructional aids process. The average achievement score obtained by students is $72.5 \%$. The results of this achievement indicate that there is a need to instill awareness to protect the environment for students, especially in managing waste and garbage from different perspectives and stimulating it from the beginning. In learning, lecturers, for example, can give examples of how the use of instructional media (instructional aids) is made from rubbish or waste. Thus, students will be more aware of wastes that are detrimental to their current environment (Kurniawati \& Atmojo, 2017). However, at present, garbage and waste are still a problem for living things and the environment if they cannot be properly controlled, managed, and reprocessed. Therefore, in addition to reducing the volume of trash and waste that damages the environment, the creation of instructional aids made from waste also increases student creativity.

Creativity is the uniqueness of the students which is indicated by the ability to create new things and develop something that already exists after seeing new relationships with existing elements and interacting with the environment to face problems and find solutions through various opinions (Maftukhah, Nur; 
Chryst, 2016). In addition, creativity is the root of innovative thinking that leads to new and useful solutions or products (DeHaan, 2011). The role of researchers in this opportunity is to provide stimulation, direction and bring out creativity to students, one of them by making instructional aids.

Instructional aids are used to practice process skills such as observing, asking questions, formulating problems and hypotheses, interpreting data, drawing conclusions and communicating in the form of practicum and learning. Instructional aids must also be used to add to the classroom experience and to provide physical depiction that helps students build mental models (Astrachan, 1998). Learning using instructional aids means optimizing the function of all five senses of students to increase the effectiveness and creativity of students in learning by listening, seeing, touching and using their thoughts logically and realistically (Budiman et al., 2016). In the process of making instructional aids, the researchers used observation sheets to assess student creativity by considering five aspects, namely: authenticity, fluency, flexibility, detailing and assessing (Fitriarosah, 2016). Each component was divided into several indicators that will be observed and assessed by researchers when the process of making instructional aids took place. Scoring awere done individually which were then counted and converted into percentage values. The individual scores were added simultaneously to obtain the grade average.

The obtained achivement score of $72.5 \%$ has indicated that the creativity of Science Education study program students at UNHASY categorized as high. These results indicate that there is an increase in the assessment of creative thinking on indicators of authenticity, in which students have a unique way of thinking and produce unique products. Then, on a detailing indicator, students have the ability to describe and generalize ideas into the production of teaching aids. Creative thinking is defined as a mental activity that is used by someone to build new ideas and opinions. Also, in creative thinking, someone will go through the stages of synthesizing ideas (Siswono, 2011), planning ideas and implementing these ideas to produce brand-new products; it is what we call creativity. Creative thinking is a habit that is trained by paying attention to intuition, animating the imagination, revealing new possibilities, opening up amazing perspectives and arousing unexpected ideas. It is important to develop student creativity as a factor to increase intellectual potential and thus there is a correlation between the level of creativity and emotionality (intelligence intelligence quotient) (Mynbayeva, Vishnevskay, \& Sadvakassova, 2016). Creative thinking tries to create something new, trying to assess or validate something that exists by implementing accepted principles (Baker, Rudd, \& Pomeroy, 2001), but getting used to fostering ideas or opinions which needs to be continually developed and trained in order to create innovative works which is more varied in the near future.

\section{Conclusion}

According to the results of this research, it can be concluded that the implementation of $5 R$ (Reduce, Reuse, Recycle, Replace, Respect) waste education programs could be followed by students enthusiastically. In addition, students were able to implement and apply the acquired knowledge based on the predetermined theme. The results also confirm that student's creativity is good in producing instructional aid for Physics lessons by utilizing waste and garbage around UNHASY. The score obtained was $72.5 \%$. This number indicates that the creativity of Science Education study program students is high. To sum up, it is reccommended to conduct a follow-up activity in producing varied instructional aids based on another lesson content to enrich student experience and knowledge references.

\section{Acknowlegdement}

The authors would like to express the greatest gratitude to the Ministry of Research, Technology, and Higher Education which provided us a research grant for Novice lecturers (PDP) financial year 2019 in accordance with 046/SP2H/LT/MONO/L7/2019

\section{References}


Afriyanto, E. (2015). Pengembangan media pembelajaran alat peraga pada materi hukum biot savart di SMA Negeri 1 Prambanan Klaten. Jurnal Riset Dan Kajian Pendidikan Fisika, 2(1), 20. https://doi.org/10.12928/jrkpf.v2i1.3131

Amalia, L. S. (2018). Daur biogeokimia sub materi siklus air kelas X SMA (Pengembangan alat peraga limbah plastik materi daur biogeokimia sub materi siklus air kelas X SMA)

Amin, M., \& Sustini, E. (2015). Perancangan alat peraga perubahan wujud zat dari limbah gelas plastik menjadi sumber energi alternatif. 2015(Snips), 37-40.

Astrachan, O. (1998). Concrete teaching: Hooks and props as instructional technology. Proceedings of the Conference on Integrating Technology into Computer Science Education, ITiCSE, Part F129252, 21-24. https://doi.org/10.1145/282991.283003

Astuti, R. (2015). Meningkatkan kreativitas siswa dalam pengolahan limbah menjadi trash fashion melalui PjBL. Bioedukasi: Jurnal Pendidikan Biologi, 8(2), 37. https://doi.org/10.20961/bioedukasiuns.v8i2.3872

Baker, M., Rudd, R., \& Pomeroy, C. (2001). Relationships between critical and creative thinking. Journal of Southern Agricultural Education Research.

Budiman, A. A., Inggriani, A. S., Prasetyo, Y. A., Fauziah, N., \& Septiana, N. (2016). Model pembelajaran IPA dengan alat peraga sederhana untuk meningkatkan pemahaman dan kreativitas siswa di MTs Ma'Arif Cikeruh, Jatinangor. Dharmakarya: Jurnal Aplikasi Ipteks Untuk Masyarakat, 5(1), 56-60. https://doi.org/10.24198/DHARMAKARYA.V5I1.8879

DeHaan, R. L. (2011). Teaching creative science thinking. Science. https://doi.org/10.1126/science.1207918

Fitriarosah, N. (2016). Pengembangan Instrumen berfikir kreatif matematis untuk siswa SMP. Prosiding Seminar Nasional Pendidikan Matematika 2016 Universitas Kanjuruhan Malang., 1(1997), 243-250.

Hartati, B. (2010). Pengembangan alat peraga gaya gesek untuk meningkatkan keterampilan berpikir kritis siswa SMA. Jurnal Pendidikan Fisika Indonesia, 6(2), 128-132. https://doi.org/10.15294/jpfi.v6i2.1125

Ikromi, S. L. (2018). Meningkatkan kemampuan berpikir kreatif matematis siswa SMA melalui pembelajaran open-ended pada materi SPLTV. Jurnal Matematika Statistika Dan Komputasi, 15(2), 104. https://doi.org/10.20956/jmsk.v15i2.5719

Kurniawati, W., \& Atmojo, S. E. (2017). Pembelajaran sains bermuatan karakter ilmiah dengan alat peraga barang bekas dan asesmen kinerja. JPI (Jurnal Pendidikan Indonesia), 6(1), 49-59. https://doi.org/10.23887/jpi-undiksha.v6i1.8866

Maftukhah, Nur; Chryst, K. S. (2016). Pemanfaatan barang bekas dalam peningkatkan kreativitas siswa pada mata pelajaran sbk kelas v sd negeri 2 karangpoh tahun ajaran 2015/2016.

Marwiyah, S., Kamid, K., \& Risnita, R. (2015). Pengembangan instrumen penilaian keterampilan berpikir kreatif pada mata pelajaran IPA terpadu materi atom, ion, dan molekul SMP Islam Al Falah. EduSains: Jurnal Pendidikan Matematika Dan Ilmu Pengetahuan Alam, 4(1).

Mynbayeva, A., Vishnevskay, A., \& Sadvakassova, Z. (2016). Experimental study of developing creativity of university students. Procedia - Social and Behavioral Sciences, 217, 407-413. https://doi.org/10.1016/j.sbspro.2016.02.113

Nggadas, D. E. P., \& Ariswan, A. (2019). The mastery of physics concepts between students are learning by ICT and laboratory experiments based-teaching. Momentum: Physics Education Journal, 2(1), 21-31. https://doi.org/10.21067/mpej.v3i1.3343

Prasetiyo, A. D., \& Mubarokah, L. (2014). Berpikir kreatif siswa dalam penerapan model pembelajaran Berdasar masalah matematika. Jurnal Pendidikan Matematika STKIP PGRI Sidoarjo, 2(1), 9-18.

Siswono, T. Y. E. (2011). Level of student's creative thinking in classroom mathematics. Educational Research and Reviews, 6(7), 548-553.

Sultoni, A., Pd, M., \& Agoestanto, A. (2013). Upaya peningkatan kemampuan berpikir kreatif dengan problem based learning berpendekatan scientific pada materi trigonometri. 106-115.

Suriawati, S., \& Mundilarto, M. (2019). SETS approach-based audiovisual media for improving the students' critical thinking skills. Psychology, Evaluation, and Technology in Educational Research, 1(2), 95-103. 
https://doi.org/10.33292/petier.v1i2.15

Sutarman, D. (2014). The development of light reflection props as a physics learning media in vocational high school number 6 Tanjung Jabung Timur. International Journal of Innovation and Scientific Research, 12(2), 346-355.

Widiyatmoko, A., \& Pamelasari, S. D. (2012). Pembelajaran berbasis proyek untuk mengembangkan ALAT peraga IPA dengan memanfaatkan bahan bekas pakai. Jurnal Pendidikan IPA Indonesia. https://doi.org/10.15294/.v1i1.2013 